\title{
PENENTUAN SETTING OPTIMUM PADA PROSES HEAT TREATMENT UNTUK MENINGKATKAN KUALITAS KEKERASAN BAJA DENGAN METODE TAGUCHI
}

\author{
Maria Ulfah, Putro Ferro Ferdinant, Riska Apriliani \\ Jurusan Teknik Industri, Fakultas Teknik, Universitas Sultan Ageng Tirtayasa \\ Jalan Jendral Sudirman KM 3 Cilegon-Banten Telp.0254 391502 \\ e-mail: maria67_ulfah@yahoo.com
}

\begin{abstract}
ABSTRAK
Pertumbuhan industri baja di Indonesia pada industri otomotif, diproyeksikan tahun 2025 akan memproduksi 3 juta unit mobil sehingga membutuhkan sebanyak 1,8 juta ton baja otomotif. Peningkatan kapasitas produksi industri baja nasional dan produksi industri baja dalam negeri terus dioptimalkan dan diarahkan pada pengembangan produk khusus bernilai tambah tinggi, dengan adanya hal tersebut, untuk mengembangkan produksi, maka diperlukan adanya upaya untuk meningkatkan kualitas baja dengan meningkatkan kekerasan dan ketahanan aus dari komponen. Upaya yang dapat dilakukan adalah melakukan proses heat treatment, tujuannya untuk mendapatkan struktur yang keras. Dalam proses heat treatment dapat digunakan desain eksperimen. Desain eksperimen yang dilakukan pada penelitian ini adalah faktorial dan Taguchi. Hasil penelitian berdasarkan hasil Anova menunjukkan bahwa faktor-faktor yang mempengaruhi respons kualitas kekerasan baja $\left(F_{\text {hitung }}>F_{\text {tabel }}\right)$ yaitu temperatur dan media, sedangkan faktor holding time tidak memiliki pengaruh yang signifikan, namun pada proses heat treatment seluruh faktor tersebut saling bergantung dan tidak bisa dihilangkan, maka faktor holding time tetap digunakan. Berdasarkan analisa yang dilakukan, setting level faktor optimum yaitu menggunakan holding time sebesar 30 menit, temperatur sebesar $900^{\circ} \mathrm{C}$, dan media pendingin air. Faktor yang paling berkontribusi terhadap respon kualitas yaitu faktor temperatur, dengan kontribusi sebesar 30,53\%.
\end{abstract}

Kata kunci: Desain Eksperimen, Heat Treatment, Kualitas, Kekerasan.

\begin{abstract}
The growth of the steel industry in Indonesia in the automotive industry, it is projected that in 2025 it will produce 3 million units of cars so as to require as much as 1,8 million tons of automative steel. The increase in production capacity of the national steel industry and the production of the domestic steel industry continue to be optimized and directed at the development of high value-added special products, in the presence of this, to develop production, efforts are needed to improve the quality of steel by increasing the hardness and wear resistance of components. The effort that can be done is to carry out the heat treatment process, the aim is to get a hard structure. In the heat treatment process an experimental design can be used. The experimental design carried out this study was factorial and taguchi. The results of the study based on Anova results indicate that the factors that influence the response of the quality of steel hardness $\left(F_{\text {aritmetic }}>F_{\text {Tabel }}\right)$ are temperature and media, while the holding time factor does not have a significant effect, but in the heat treatment process all of these factors are interdependent and cannot be eliminated, then the holding time factor is still used. Based on the analysis conducted, the optimum factor level setting is using a holding time of 30 minutes, a temperature of $900^{\circ} \mathrm{C}$, and a water cooling media. The most contributing factor to the quality response is the temperature factor, with a contribution of $30,53 \%$.
\end{abstract}

Keywords: Design Experiments, Heat Treatment, Quality, Hardness.

\section{PENDAHULUAN}

Pertumbuhan industri baja di Indonesia pada industri otomotif, diproyeksikan tahun 2025 akan memproduksi 3 juta unit mobil sehingga membutuhkan sebanyak 1,8 juta ton baja otomotif. Kemenperin pun semakin memacu peningkatan kapasitas produksi industri baja nasional, produksi industri baja dalam negeri terus dioptimalkan dan diarahkan pada pengembangan produk khusus bernilai tambah tinggi, misalnya untuk sektor otomotif, sehingga kita tidak perlu lagi impor. Dengan adanya hal tersebut, untuk mengembangkan produksi, diperlukan adanya upaya untuk meningkatkan kualitas baja dengan 
meningkatkan kekerasan dan ketahanan aus dari komponen.Kualitas suatu produk dapat diukur berdasarkan kecocokan antar performansi aktual yang ditunjukkan oleh suatu produk terhadap spesifikasi standar yang ditetapkan/dipersyaratkan oleh konsumen. Dalam upaya menghasilkan produk dengan deviasi minimum dari targetnya, maka terus melakukan pengendalian proses [1].

Upaya untuk dapat meningkatkan kekerasan dan ketahanan aus dari bahan tersebut, dapat dilakukan melalui proses heat treatment, tujuannya untuk mendapatkan struktur yang keras [2]. Proses heat treatment dilakukan dengan menggunakan desain eksperimen. Eksperimen dapat menghasilkan setting level terbaik dari faktor-faktor terkait yang bertujuan untuk meningkatkan kualitas. Desain eksperimen yang digunakan pada penelitian ini adalah eksperimen faktorial dan eksperimen Taguchi.

Tujuan penelitian yang dilakukan pada penelitian ini adalah menentukan faktor berpengaruh pada proses heat treatment terhadap respons kualitas, menentukan setting level dari faktor berpengaruh, menentukan respons kualitas dengan melakukan eksperimen rancangan parameter Taguchi, dan menentukan setting level faktor optimum proses heat treatment untuk menghasilkan respons kualitas yang sesuai.

\section{METODE PENELITIAN \\ Rancangan Penelitian}

Rancangan penelitian yang digunakan dalam eksperimen pada proses heat treatment adalah eksperimen dengan desain faktorial $3 \times 3 \times 3$ atau $3^{3}$ dan dengan eksperimen Taguchi, desain faktorial $3^{3}$ berarti memiliki 3 faktor pengaruh yaitu temperatur, holding time, dan media pendinginan, dimana replikasi yang digunakan masing masing 2 , kemudian diamati akibat atau dampak dari perlakuan tersebut pada variabel respon atau terikat dengan menguji tingkat kekerasan. Dari eksperimen yang dilakukan, didapatkan hasil data primer berupa nilai kekerasan pada setiap kombinasi eksperimen, yang kemudian diolah dan dianalisa menggunakan metode faktorial dan Taguchi, sehingga didapatkan setting level faktor optimum yang dapat digunakan. Teknik analisis data yang digunakan bersifat kuantitatif dengan tujuan untuk menguji hipotesis yang telah ditetapkan.

\section{Alur Penelitian}

Alur penelitian dapat digambarkan melalui flow chart pemecahan masalah dan flow chart eksperimen heat treatment seperti ditunjukkan pada Gambar 1 dan Gambar 2.

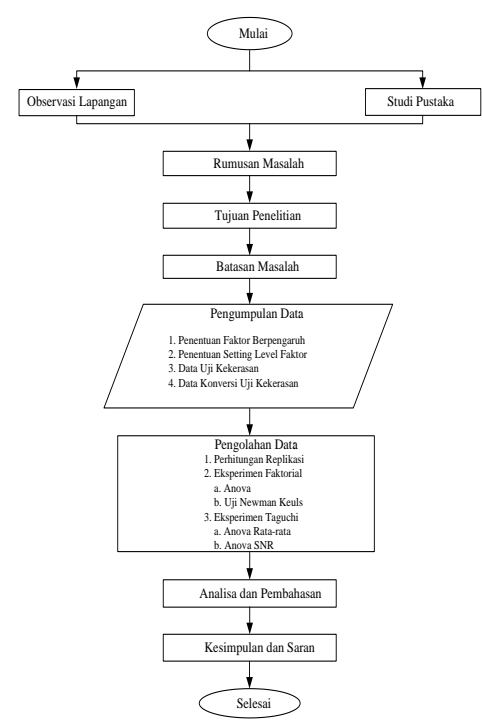

Gambar 1. Flow Chart Pemecahan Masalah

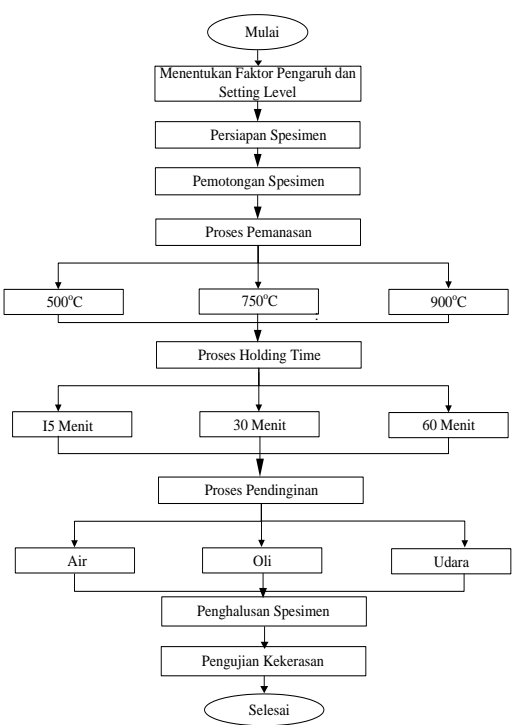

Gambar 2. Flow Chart Eksperimen Heat Treatment 


\section{HASIL DAN PEMBAHASAN}

\section{Pengumpulan Data}

Pengumpulan data pada penelitian ini terdiri dari penentuan faktor berpengaruh, penentuan setting level, dan data uji kekerasan (Vickers).

1. Penentuan faktor berpengaruh

Faktor-faktor yang diduga berpengaruh terhadap nilai kekerasan baja yaitu holding time, temperatur, dan media pendingin

2. Penentuan setting level

Setting level untuk faktor-faktor yang dilibatkan dalam eksperimen yaitu holding time terdiri dari level 15 menit, 30 menit, dan 60 menit. Faktor temperatur terdiri dari $500^{\circ} \mathrm{C}, 750^{\circ} \mathrm{C}$, dan $900^{\circ} \mathrm{C}$. Faktor media pendingin terdiri dari air, oli dan udara.

3. Data uji kekerasan (Vickers)

Dari eksperimen yang telah dilakukan, didapatkan data hasil berupa data primer uji kekerasan. Berikut data pada Tabel 1 adalah uji kekerasan yang dilakukan:

Tabel 1. Data Uji Kekerasan (Vickers)

\begin{tabular}{cccccccccc} 
& \multicolumn{9}{c}{ Holding Time (Menit) } \\
\cline { 2 - 11 } Media & \multicolumn{4}{c}{15} & \multicolumn{9}{c}{30} & \multicolumn{3}{c}{60} \\
& 500 & 750 & 900 & 500 & 750 & 900 & 500 & 750 & 900 \\
\hline \multirow{2}{*}{ Air } & 382,00 & 423,33 & 528,33 & 382,00 & 363,64 & 720,00 & 392,00 & 382,00 & 745,71 \\
& 345,83 & 337,00 & 512,86 & 354,55 & 318,33 & 708,89 & 345,83 & 354,55 & 697,50 \\
\hline \multirow{2}{*}{ Oli } & 314,17 & 310,00 & 345,83 & 363,64 & 354,55 & 446,25 & 327,27 & 345,83 & 417,78 \\
& 392,00 & 354,55 & 402,00 & 337,00 & 337,00 & 392,00 & 354,55 & 327,27 & 392,00 \\
\hline \multirow{2}{*}{ Udara } & 337,00 & 345,83 & 382,00 & 310,00 & 310,00 & 318,33 & 392,00 & 327,27 & 310,00 \\
& 363,64 & 341,67 & 354,55 & 318,33 & 293,57 & 392,00 & 318,33 & 318,33 & 318,33 \\
\hline
\end{tabular}

\section{ANALISIS}

\section{Analisa Replikasi}

Dalam perancangan eksperimen Taguchi, penanganan faktor noise dapat melalui tiga cara, yaitu: [3]

1. Dengan melakukan pengulangan terhadap masing-masing percobaan

2. Dengan memasukkan faktor noise ke dalam eksperimen dengan menempatkannya diluar faktor kendali.

3. Dengan menganggap faktor terkendali bervariasi.

Replikasi adalah pengulangan kembali perlakuan yang sama dalam suatu eksperimen dengan kondisi yang sama untuk memperoleh ketelitian yang lebih tinggi. Replikasi bertujuan untuk mengurangi tingkat kesalahan eksperimen dan menambah ketelitian data eksperimen.

Penentuan jumlah replikasi pada penelitian ini menggunakan rumus Federer [4] untuk menghindari sekecil mungkin kesalahan dalam replikasi atau pengulangan terhadap eksperimen, digunakan rumus :

$$
\begin{array}{rlrl}
(\mathrm{t}-1)(\mathrm{r}-1) & \geq 15 \quad \text { Dimana: } & \mathrm{t}=\text { Jumlah Perlakuan } \\
(27-1)(\mathrm{r}-1) & \geq 15 & & \mathrm{r}=\text { Jumlah Pengulangan/replikasi } \\
27 \mathrm{r}-27-\mathrm{r}+1 & \geq 15 & & \\
26 \mathrm{r} & \geq 15+26 & \\
26 \mathrm{r} & \geq 41 & \\
\mathrm{r} & \geq 1,576 \sim 2 &
\end{array}
$$


Penentuan Setting Optimum pada Proses Heat Treatment untuk Meningkatkan Kualitas Kekerasan Baja dengan Metode Taguchi

Maria Ulfah, Putro Ferro Ferdinant, Riska Apriliani

Dari hasil perhitungan, didapatkan jumlah pengulangan sebanyak 2 kali pada masingmasing perlakuan.

\section{Analisa Eksperimen Faktorial}

Eksperimen faktorial merupakan eksperimen yang mengkombinasikan atau menyilangkan semua faktor tertentu terhadap tiap level dari faktor lainnya yang ada dalam eksperimen tersebut [5].

Perhitungan dengan eksperimen faktorial $3^{3}$ terdiri dari uji Anova yang dilakukan untuk mengetahui faktor yang berpengaruh/tidak berpengaruh terhadap variabel respon, sedangkan uji pasca Anova digunakan untuk mengetahui perlakuan yang paling berpengaruh sehingga terdapat perbedaan yang signifikan. Uji pasca Anova yang digunakan adalah uji Newman Keuls. Eksperimen yang dilakukan menggunakan desain eksperimen faktorial menghasilkan 54 data kekerasan baja. Penelitian ini menggunakan desain eksperimen dengan 3 faktor, 3 level, dan 2 replikasi. Replikasi eksperimen dilakukan agar menambah ketelitian hasil eksperimen.

\section{Analisa Uji Anova (Analysis of Variance)}

Tahapan uji Anova terdiri dari perhitungan nilai-nilai Anova, dan pengujian hipotesis, seperti ditunjukkan pada Tabel 2.

Tabel 2. Hasil Pengujian Anova

\begin{tabular}{ccccc}
\hline Source & $\mathbf{D f}$ & $\mathbf{F}_{\text {test }}$ & $\begin{array}{c}\mathbf{F}_{\text {tabel }} \\
\mathbf{F}_{\boldsymbol{\alpha}=\mathbf{0 , 0 5}(\mathbf{v 1} \mathbf{v} \mathbf{2})}\end{array}$ & Kesimpulan \\
\hline $\mathrm{A}$ & 2 & 1,59 & 3,35 & $\mathrm{H}_{0}$ diterima \\
$\mathrm{B}$ & 2 & 98,88 & 3,35 & $\mathrm{H}_{0}$ ditolak \\
$\mathrm{C}$ & 2 & 89,77 & 3,35 & $\mathrm{H}_{0}$ ditolak \\
$\mathrm{A} \times \mathrm{B}$ & 4 & 5,22 & 2,73 & $\mathrm{H}_{0}$ ditolak \\
$\mathrm{A} \times \mathrm{C}$ & 4 & 4,48 & 2,73 & $\mathrm{H}_{0}$ ditolak \\
$\mathrm{B} \times \mathrm{C}$ & 4 & 49,76 & 2,73 & $\mathrm{H}_{0}$ ditolak \\
$\mathrm{A} \times \mathrm{B} \times \mathrm{C}$ & 8 & 3,83 & 2,31 & $\mathrm{H}_{0}$ ditolak \\
Error & 27 & & & \\
total & 53 & & & \\
\hline
\end{tabular}

Dari tabel Anova di atas, dapat terlihat hipotesis yang dihasilkan yaitu terdapat satu treatment yaitu holding time (A) dimana $\mathrm{H}_{0}$ diterima yang artinya tidak terdapat perbedaan yang signifikan, sedangkan untuk treatment temperatur dan media $\mathrm{H}_{0}$ ditolak, yang berarti terdapat perbedaan yang signifikan.

\section{Analisa Uji Newman Keuls}

Uji Newman Keuls, bertujuan untuk membandingkan semua perlakuan dan melihat adakah perbedaan dari setiap perlakuan pada masing-masing faktor. Pemilihan level dari setiap faktor kontrol pada proses heat treatment dipilih dengan membandingkan harga ratarata dengan nilai least significant range. Berikut adalah perbandingan nilai setiap faktor serta pemilihan level yang digunakan:

1. Temperatur

Temperatur merupakan faktor yang berpengaruh secara signifikan terhadap nilai kekerasan baja. Berdasarkan tabel Anova, temperatur memiliki nilai $F_{\text {test }}$ sebesar 98,886 dan nilai $\mathrm{F}_{\text {tabel }}$ sebesar 3,35 sehingga pada faktor temperatur $\mathrm{H}_{0}$ ditolak. Dari pengujian uji Newman Keuls yang membandingkan level pada faktor temperatur, yaitu antara level $900^{\circ} \mathrm{C}$ dan $500^{\circ} \mathrm{C}, 900^{\circ} \mathrm{C}$ dan $750^{\circ} \mathrm{C}$, didapatkan hasil adanya perbedaan yang signifikan atau perbedaan yang berarti pada perbandingan tersebut, namun perbandingan temperatur $500^{\circ} \mathrm{C}$ dan $750^{\circ} \mathrm{C}$ didapatkan hasil tidak adanya perbedaan yang signifikan. Level faktor 
yang memiliki pengaruh paling besar adalah level 3 atau level $900^{\circ} \mathrm{C}$ karena memiliki nilai rata-rata tertinggi, oleh karena itu $900^{\circ} \mathrm{C}$ dipilih sebagai level optimal.

\section{Media Pendinginan}

Media merupakan faktor yang berpengaruh secara signifikan terhadap nilai kekerasan baja. Berdasarkan tabel Anova, media memiliki nilai $\mathrm{F}_{\text {test }}$ sebesar 89,778 dan nilai $\mathrm{F}_{\text {tabel }}$ sebesar 3,35 sehingga pada faktor media $\mathrm{H}_{0}$ ditolak. Dari pengujian uji Newman Keuls yang membandingkan level pada faktor media pendinginan, yaitu antara level media air dan udara, air dan oli, serta oli dan udara didapatkan hasil adanya perbedaan yang signifikan pada perbandingan level tersebut. Level faktor yang memiliki pengaruh paling besar adalah level 1 atau level air karena memiliki nilai rata-rata tertinggi, oleh karena itu media air dipilih sebagai level optimal.

\section{Holding time}

Holding time merupakan faktor yang tidak berpengaruh secara signifikan terhadap kekerasan baja, namun karena pada proses heat treatment faktor-faktor tersebut saling ketergantungan, yang tidak mungkin dihilangkan, maka faktor holding time tetap digunakan dan pemilihan level tetap dilakukan dengan menggunakan uji Newman Keuls. Dari uji Newman Keuls yang membandingkan level pada faktor holding time, yaitu antara level 60 menit dan 15 menit, 60 menit dan 30 menit, serta 30 menit dan 15 menit didapatkan hasil nilai rata-rata < nilai least significant range yang berarti tidak adanya pengaruh yang signifikan dari setiap level pada faktor holding time. Level faktor yang dipilih sebagai level faktor optimum berdasarkan nilai rata-rata adalah level 60 menit, karena memiliki nilai rata-rata yang paling besar.

\section{Analisa Eksperimen Taguchi}

Untuk mengurangi jumlah dari eksperimen full factorial design, maka untuk menyederhanakannya dikenal metode fraction factorial design. Metode yang digunakan dalam analisa Taguchi untuk mengetahui signifikansi kontribusi dari setiap parameter yang mempengaruhi proses heat treatment adalah menggunakan Anova, dimana akan diketahui kontribusi setiap perlakuan terhadap nilai SNR dan nilai rata-rata. Berikut Tabel 3 standard untuk orthogonal array yang ditabulasi oleh Taguchi: [6].

Tabel 3. Tabel Orthogonal Array Standard

\begin{tabular}{ccccc}
\hline 2 Level & 3 Level & 4 Level & 5 Level & Mixed-Level \\
\hline $\mathrm{L}_{4}\left(2^{3}\right)$ & $\mathrm{L}_{9}\left(3^{4}\right)$ & $\mathrm{L}_{16}\left(4^{5}\right)$ & $\mathrm{L}_{25}\left(5^{6}\right)$ & $\mathrm{L}_{18}\left(2^{1} \times 3^{7}\right)$ \\
$\mathrm{L}_{8}\left(2^{7}\right)$ & $\mathrm{L}_{27}\left(3^{13}\right)$ & $\mathrm{L}_{64}\left(4^{21}\right)$ & - & $\mathrm{L}_{32}\left(2^{1} \times 4^{9}\right)$ \\
$\mathrm{L}_{12}\left(2^{11}\right)$ & $\mathrm{L}_{81}\left(3^{40}\right)$ & - & - & $\mathrm{L}_{36}\left(2^{11} \times 3^{12}\right)$ \\
$\mathrm{L}_{16}\left(2^{15}\right)$ & - & - & - & $\mathrm{L}_{36}\left(2^{3} \times 3^{13}\right)$ \\
$\mathrm{L}_{32}\left(2^{31}\right)$ & - & - & - & $\mathrm{L}_{54}\left(2^{1} \times 3^{25}\right)$ \\
$\mathrm{L}_{64}\left(2^{63}\right)$ & - & - & - & $\mathrm{L}_{50}\left(2^{1} \times 3^{11}\right)$ \\
\hline
\end{tabular}

\section{Analisa Anova Nilai Rata-rata Eksperimen Taguchi}

Untuk mengetahui faktor-faktor yang signifikan berpengaruh terhadap nilai rata-rata kekerasan baja atau faktor penyesuai rata-rata yaitu faktor yang signifikan terhadap sensitivitas, maka perlu dilakukan analisa dengan menggunakan Anova. Analisa ini juga untuk memastikan hasil dari perhitungan faktor yang signifikan berpengaruh terhadap ratarata nilai kekerasan yang telah didapatkan.

Berdasarkan pengolahan data yang dilakukan dengan menggunakan Anova, faktorfaktor yang signifikan berkontribusi pada nilai rata-rata kekerasan baja adalah faktor-faktor yang memberikan efek pada ketepatan performa karakteristik kualitas kekerasan baja. 
Penentuan Setting Optimum pada Proses Heat Treatment untuk Meningkatkan Kualitas Kekerasan Baja dengan Metode Taguchi

\section{Maria Ulfah, Putro Ferro Ferdinant, Riska Apriliani}

Dengan membandingkan nilai $\mathrm{F}_{\text {ratio }}$ dan $\mathrm{F}_{\text {tabel }}$ masing-masing faktor, dapat diketahui faktor yang memiliki pengaruh signifikan terhadap kekerasan baja pada proses heat treatment. Jika nilai $F_{\text {ratio }}$ dari faktor lebih besar dari nilai $F_{\text {tabel }}$, maka dapat disimpulkan bahwa faktor tersebut memiliki pengaruh yang signifikan terhadap variabel respon (dalam hal ini adalah kekerasan baja). Dengan melakukan perbandingan tersebut, maka dapat disimpulkan ada 2 faktor utama yang berpengaruh terhadap nilai rata-rata kekerasan baja dan memiliki efek yang cukup besar terhadap nilai kekerasan baja. Faktor tersebut adalah faktor B dan C, dimana faktor $\mathrm{B}$ adalah temperatur pemanasan dan faktor $\mathrm{C}$ adalah media pendinginan. Dari tabel yang sama, dapat juga dilihat seberapa besar kontribusi yang diberikan oleh masing-masing faktor berdasarkan persen ratio. Besarnya kontribusi faktor masing-masing adalah faktor B yaitu temperatur dengan persen kontribusi sebesar 33,40\%, kemudian faktor $\mathrm{C}$ yaitu media pendinginan dengan persen kontribusi $24,02 \%$, dan faktor $\mathrm{C}$ yaitu holding time dengan persen kontribusi sebesar 9,80\%.

Hasil tabel Anova nilai rata-rata dapat diketahui bahwa faktor A atau faktor holding time tidak berpengaruh secara signifikan terhadap variabel respon, dikarenakan hal tersebut, maka dilakukan pooling up terhadap faktor yang kurang signifikan. Syarat metode Taguchi untuk persen kontribusi $\leq 50 \%$ dikatakan signifikan [7]. Dengan melakukan perbandingan maka dapat disimpulkan faktor A dan faktor B memiliki efek yang cukup besar terhadap nilai kekerasan baja, dimana faktor B adalah temperatur pemanasan dan faktor $\mathrm{C}$ adalah media pendinginan. Dari tabel yang sama, dapat juga dilihat seberapa besar kontribusi yang diberikan oleh masing-masing faktor berdasarkan persen ratio. Besarnya kontribusi faktor masing-masing adalah faktor B yaitu temperatur dengan persen kontribusi sebesar $31,89 \%$, kemudian faktor $\mathrm{C}$ yaitu media pendinginan dengan persen kontribusi 22,51\%.

\section{Analisa Taguchi Anova Nilai SNR}

Untuk mengetahui faktor-faktor yang signifikan berpengaruh terhadap nilai SNR kekerasan baja atau faktor pengontrol dispersi yaitu faktor yang signifikan kokoh terhadap faktor gangguan maka perlu dilakukan analisa dengan menggunakan Anova.

Berdasarkan pengolahan data yang dilakukan dengan menggunakan Anova, diketahui bahwa faktor-faktor yang signifikan berkontribusi terhadap SNR adalah parameter yang tidak sensitif terhadap perubahan atau gangguan yang menyebabkan variasi. Dari tabel Anova untuk SNR, dapat dilihat bahwa dengan membandingkan nilai $\mathrm{F}_{\text {ratio }}$ masing-masing faktor, apabila nilai $\mathrm{F}_{\text {ratio }}>\mathrm{F}_{\text {tabel }}$, maka dapat disimpulkan bahwa faktor tersebut memiliki pengaruh yang signifikan terhadap variabel respon (dalam hal ini adalah kekerasan baja).

Dengan melakukan perbandingan tersebut, tidak terdapat satu pun faktor yang signifikan kokoh terhadap faktor gangguan. Dengan adanya hasil tersebut, maka evaluasi terhadap pengawasan faktor gangguan perlu ditingkatkan.

\section{Analisa Penentuan Setting Level Optimal}

Dari analisa sebelumnya, telah ditentukan faktor-faktor yang signifikan berkontribusi baik terhadap SNR maupun nilai rata-rata kekerasan baja. Hasil inilah yang akan dianalisa lebih lanjut untuk menentukan setting level faktor heat treatment yang optimum.

Kombinasi yang optimal dipilih berdasarkan pertimbangan antara faktor-faktor terkontrol yang mungkin berkontribusi untuk mengurangi variasi dan meningkatkan kualitas dapat diidentifikasi dengan menggunakan jumlah variasi pada keadaan sekarang dan pergeseran rata-rata respons kualitas. Seperti yang telah diketahui dari hasil pengolahan data bahwa faktor-faktor terkontrol terbagi menjadi tiga yaitu faktor yang signifikan terhadap variansi yang direfleksikan terhadap SNR, faktor kontrol yang 
signifikan berkontribusi menggeser nilai rata-rata respon kualitas dan faktor yang tidak signifikan di keduanya. Berikut Tabel 4 adalah rekapitulasi pembagian faktor kontrol yang signifikan:

Tabel 4. Pembagian Faktor Terkontrol

\begin{tabular}{lcl}
\hline $\begin{array}{l}\text { Faktor signifikan } \\
\text { terhadap nilai rata-rata }\end{array}$ & $\begin{array}{l}\text { Faktor signifikan } \\
\text { terhadap nilai SNR }\end{array}$ & Faktor tidak signifikan \\
\hline $\begin{array}{l}\text { Temperatur } \\
\text { Media }\end{array}$ & - & Holding Time \\
\hline
\end{tabular}

Pemilihan level dari setiap faktor kontrol pada proses heat treatment adalah sebagai berikut:

1. Temperatur, adalah faktor yang signifikan berpengaruh terhadap nilai rata-rata respon kualitas, berdasarkan tabel Anova rata-rata, diketahui bahwa kontribusi faktor ini adalah sebesar $31,89 \%$, sehingga pemilihan level optimalnya harus memperhatikan level optimal untuk rata-rata kekerasan baja. Berdasarkan response tabel nilai rata-rata tiap level faktor menunjukkan bahwa level optimal yang dipilih untuk level temperatur adalah level 3 yaitu sebesar $900^{\circ} \mathrm{C}$. Dapat diketahui pemanasan dengan temperatur $900^{\circ} \mathrm{C}$ pada baja menengah tipe AISI 1045, akan menghasilkan fasa berupa austenit. Temperatur pemanasan, austenisasi berpengaruh terhadap nilai kekerasan yang dimiliki oleh komponen. Pada temperatur austenisasi butir-butir austenit akan tumbuh. Pada butiran austenit yang besar, luas batas butir atau jumlah titik sebagai tempat pengintian terjadinya dekomposisi fasa austenit menjadi pearlit akan semakin rendah, hal ini akan memudahkan transformasi austenit menjadi martensit, dan akan menghasilkan baja yang memiliki kemampukerasan yang lebih tinggi.

2. Media pendinginan, merupakan faktor yang hanya berpengaruh signifikan terhadap nilai rata-rata kekerasan baja, sehingga untuk pemilihan level optimalnya adalah yang memiliki nilai paling tinggi. Berdasarkan response tabel faktor media pada nilai ratarata, level optimal yang dipilih adalah level 1, yaitu media air. Pendinginan dengan menggunakan air akan memberikan daya pendinginan yang cepat, dengan kecepatannya menurunkan temperatur pada benda kerja akan mengakibatkan bahan memiliki sifat yang keras. Pendinginan akan menyebabkan austenit bertransformasi dan struktur mikro yang terbentuk akan sangat tergantung pada laju pendinginan. Perubahan suhu air berlangsung lambat sehingga air memiliki sifat sebagai penyimpan panas yang sangat baik. Sifat ini memungkinkan air tidak menjadi panas atau dingin dalam seketika. Air memerlukan panas yang tinggi dalam proses penguapan. Kemudian, jika dilihat dari segi densitas (massa jenis), air memiliki densitas yang lebih besar dibandingkan dengan oli [8].

3. Holding Time, merupakan faktor yang tidak signifikan berpengaruh berdasarkan tabel Anova, baik terhadap SNR maupun nilai rata-rata kekerasan baja, namun karena pada proses heat treatment faktor-faktor tersebut saling ketergantungan, yang tidak mungkin dihilangkan, maka faktor holding time tetap digunakan dan pemilihan level dapat dilihat pada response tabel nilai rata-rata maupun nilai SNR, karena kedua response tabel menghasilkan level faktor optimal yang sama yaitu pada level kedua atau 30 menit. Pemberian holding time atau waktu tahan pada proses pemanasan bertujuan untuk memberikan kesempatan atom-atom untuk berdifusi menghomogenkan austenit. Dengan holding time 30 menit, waktu penahanan tidak terlalu pendek yang akan mengakibatkan kekerasan yang rendah karena tidak cukupnya jumlah karbida yang larut dalam larutan, dan juga tidak terlalu lama yang akan mengakibatkan pertumbuhan butir dan dapat menurunkan ketangguhan. Holding time atau waktu penahanan pada proses pemanasan dapat pula dihitung berdasarkan ketebalan komponen. 
Penentuan Setting Optimum pada Proses Heat Treatment untuk Meningkatkan Kualitas Kekerasan Baja dengan Metode Taguchi

\section{Maria Ulfah, Putro Ferro Ferdinant, Riska Apriliani}

Dari seluruh tahapan penentuan setting level faktor yang optimum, dapat kita ketahui faktor setting level yang digunakan dalam proses heat treatment yaitu faktor holding time dengan level 30 menit, faktor temperatur dengan level $900^{\circ} \mathrm{C}$, dan faktor media pendingin dengan level air, kemudian dapat juga dilihat pada nilai kekerasan yang dihasilkan, dengan dilakukan eksperimen proses heat treatment, setting level di atas didapatkan nilai kekerasan sebesar 745,71 Vickers dan 697,50 Vickers, nilai tersebut meningkat jika spesimen tidak diberi perlakuan eksperimen, yang hanya memiliki nilai kekerasan sebesar 243,50 Vickers.

Berikut adalah Tabel 5 setting level yang ditentukan:

Tabel 5. Penentuan Setting Level

\begin{tabular}{cccc}
\hline & Faktor & Level & Setting \\
\hline A & Holding Time & 2 & 30 menit \\
B & Temperatur & 3 & $900^{\circ} \mathrm{C}$ \\
C & Media & 1 & Air \\
\hline
\end{tabular}

Dari tabel 5 dapat diketahui faktor setting level usulan yang dapat digunakan dalam proses heat treatment yaitu faktor holding time dengan level 30 menit, faktor temperatur dengan level $900^{\circ} \mathrm{C}$, dan faktor media pendingin dengan level air.

\section{KESIMPULAN}

Berdasarkan hasil penelitian dan analisa dalam penelitian mengenai eksperimen proses heat treatment untuk meningkatkan kualitas kekerasan baja, maka dapat disimpulkan yaitu 1).Faktor-faktor yang berpengaruh pada proses heat treatment terhadap respons kualitas adalah holding time, temperatur, dan media pendinginan. 2). Setting level untuk faktor-faktor yang dilibatkan dalam dalam eksperimen yaitu pada faktor holding time menggunakan tiga level, terdiri dari 15 menit, 30 menit, dan 60 menit.

Faktor temperatur menggunakan tiga level terdiri dari $500^{\circ} \mathrm{C}, 750^{\circ} \mathrm{C}, 900^{\circ} \mathrm{C}$, dan faktor media pendinginan menggunakan tiga level yang terdiri dari air, oli dan udara. 3). Setelah dilakukan eksperimen, maka didapatkan faktor-faktor yang berpengaruh secara signifikan terhadap respon kualitas kekerasan, dan faktor yang paling berkontribusi terhadap respon kualitas yaitu faktor temperatur dengan kontribusi sebesar 30,53\%. 4). Setting level faktor optimum proses heat treatment untuk meningkatkan kualitas kekerasan yaitu dengan menggunakan faktor holding time dengan level 30 menit, faktor temperatur dengan level $900^{\circ} \mathrm{C}$, dan faktor media pendingin dengan level air.

Adapun saran sebagai masukan untuk penelitian selanjutnya adalah sebagai berikut 1).Dapat menggunakan faktor media pendingin yang lebih kompleks sesuai pengembangan dari faktor media yang umum seperti air garam, air dengan agitasi, dan sebagainya untuk dapat menghasilkan kualitas yang lebih baik.

2). Dalam melakukan eksperimen, faktor noise dapat dipertimbangkan untuk dimasukkan dalam matriks orthogonal array, seperti pengambilan eksperimen sesuai shift, guna mendapatkan hasil yang lebih baik.

\section{DAFTAR PUSTAKA}

[1]. Ulfah M, E, Ratna, dan F.F.Putro, 2018, Penentuan Setting Parameter Optimum Proses Pembuatan Sabun Cair Pencuci Piring Dengan Pendekatan Factorial Experiment dan Metode Taguchi. Proceeding Manajemen dan Rekayasa Kualitas. Seminar Nasional VII. Bandung, 15 November 2018.

[2]. Pramono, A., 2011, Karakterisrik Mekanik Proses Hardening Baja AISI 1045 Media Quenching Untuk Aplikasi Sprochet Rantai. Jurnal Ilmiah Teknik Mesin. Vol. 5 No. 1: $32-38$. 
[3]. Farikhatin, E., 2010, Perancangan Parameter Taguchi untuk Optimasi Proses Coating Tablet dengan Model Artificial Neural Network pada Industri Farmasi. Skripsi. Depok: Program Studi Teknik Industri Universitas Indonesia.

[4]. Muntaha, A. Haitami dan Hayati, N., 2015, Perbandingan Penurunan Kadar Formalin pada Tahu yang Direbus dan Direndam Air Panas. Medical Laboratory Technology Journal. ISSN: 2461-0879.

[5]. Cahyo, I. Adianto, dan H. Herni, F., 2014, Usulan Kombinasi Faktor-faktor yang Berpengaruh Secara Signifikan Terhadap Kuat Tekan Bata Ekspose dengan Metode Perancangan Eksperimen. Jurnal Online Institut Teknologi Nasional. Vol. 2 No. 3 : $48-59$.

[6]. Belavendram, N., 1995, Quality by Design: Taguchi Techniques for Industrial Experimentation. Prentice-Hall International.

[7]. Prasetya, C. Rahman, A. Efranto, R. Y., 2013, Analisa Desain Eksperimen Pembuatan Batako Berbahan Alternatif Lumpur Lapindo dan Fly Ash dengan Metode Taguchi. Malang: Universitas Brawijaya.

[8]. Murtiono., 2012, Pengaruh Quenching dan Tempering Terhadap Kekerasan dan Kekuatan Tarik Serta Struktur Mikro Baja Karbon Sedang Untuk Mata Pisau. Jurnal e-Dinamis.Vol. 2 No. 2. ISSN 2338-1025.57. 